\title{
Influence of Zirconia Addition on the Sintering Behavior of Bimodal Size Distributed Alumina Powder Mixtures
}

\author{
Seiichi TARUTA, Kazuo KAWASHIMA†, Kunio KITAJIMA, Nobuo TAKUSAGAWA, \\ Kiyoshi OKADA* and Nozomu ŌTSUKA** \\ Department of Chemistry and Material Engineering, Faculty of Engineering, Shinshu University, 500, Wakasato, Nagano-shi 380 \\ * Department of Inorganic Materials, Faculty of Engineering, Tokyo Institute of Technology, 2-12-1, Ookayama, Meguro-ku, Tokyo 152 \\ **Department of Materials, Faculty of Science and Engineering, The Nishi Tokyo University, 2525, Yatsusawa, Uenohara-machi, \\ Kitatsuru-gun, Yamanashi 409-01
}

\author{
粒度の異なるアルミナ混合粉体の焼結挙動に与えるジルコニア添加の影響 \\ 樽田誠一・川嶋一雄 ${ }^{\dagger} \cdot$ 北島图夫 ・田草川信雄・岡田 清*。大津賀 望** \\ 信州大学工学部物質工学科, 380 長野市若里 500 \\ *東京工業大学工学部無機材料工学科, 152 東京都目黒区大岡山 2-12-1 \\ **西東京科学大学理工学部物質工学科, 409-01 山梨県北都留郡上野原町八ッ沢 2525
}

[Received July 28, 1993; Accepted November 16, 1993]

Fine zirconia powder was added to the bimodal size distributed alumina powder mixtures and the infiluence of zirconia addition on the sintering behavior of the powder mixtures was investigated. At low firing temperature, that is, in the initial stage of sintering, zirconia retarded the densification of the powder mixtures and also enlarged the pore size of the compacts. At high firing temperature, the influence of zirconia addition was different depending on the packing structure of the green compact. When the coarse alumina particles were dispersed in the matrix of the fine particles, zirconia promoted the densification of the mixtures. This result was explained by the promotion of the densification between the fine and the coarse alumina particles in the intermediate stage of sintering and by the migration of zirconia and the hindrance effect of zirconia on the grain growth of alumina in the final stage of sintering. When the coarse alumina particles formed a skeletal structure, zirconia did not promote the densification of the mixtures. This result was explained by the dependence of the densification of the compacts only on the densification among the coarse alumina particles.

Key-words: Fine and coarse alumina powders, Zirconia powder, Sintering, Densification, Pore size, Microstructure

\section{Introduction}

It is known that green compact consisting of different powders in particle size has high packing density. Many reports on the packing structure and the packing ratio of these powder mixtures have been presented. We reported the packing and the sintering behavior of bimodal size distributed powder mixtures using spherical alumina particles.1)-3) Our

\footnotetext{
† Now with Matsushita Electric Works, Ltd., 19, Deba, Rittoucho, Kurita-gun, Shiga 520-30

現在 : 松下電工(株) 栗東工場, 520-30 滋賀県栗太郡栗東町 大字出庭 19
}

results showed that the densification behavior of the powder mixtures depends on the mixing ratio and the packing structure of fine and coarse particles. However, it was difficult to obtain dense sintered compacts because of remarkable grain growth and pore enlargement during the firing though the green compacts had higher density.

Many reports on zirconia-toughened alumina ceramics have been presented. However, most of the reports are the studies of the mechanical properties and a few of the reports are the studies of the sintering. The sintering process of those ceramics is explained as follows; zirconia retards the densification among alumina particles, particularly, in the initial stage of sintering because zirconia acts as an inclusion for alumina particles. $\left.{ }^{4)}, 5\right)$ Also, zirconia hinders the grain growth of alumina in the final stage of sintering.5)-8) This hindrance for the grain growth is effective on the densification of the alumina powder containing zirconia.5) Then, it was expected that the densification of the bimodal size distributed alumina powder mixtures would be promoted by zirconia addition because it hinders the grain growth of alumina. However, there is no study of sintering of bimodal size distributed alumina powder mixtures to which zirconia or other components is added as far as we examined the literatures.

In this study, the influence of zirconia addition on the sintering of the alumina powder mixtures consisting of the fine and the coarse particles was investigated on the base of the comparison of relative density, pore size distribution and microstructure of the compacts containing zirconia with those of the compacts containing no zirconia. And also the influence of zirconia addition on the sintering of green compacts which have different packing structures was discussed because the packing structure changes according to the mixing ratio of the fine and the coarse powders. 


\section{Experimental procedures}

\subsection{Starting materials}

Starting materials were a coarse alumina powder with the particle size of above $3 \mu \mathrm{m}$ in Stokes' diameter, which was classified from commercial alumina powder (ALM-44; Sumitomo Chemical Co.), a fine alumina powder (AES-12; Sumitomo Chemical Co.) and a zirconia powder containing $3 \mathrm{~mol} \% \mathrm{Y}_{2} \mathrm{O}_{3}$ (TZ-3Y; Toso Co.). The average particle sizes of those powders, measured with centrifugal particle size analyzer (CP-50: Shimadzu Co.), were $4.68 \mu \mathrm{m}$, $0.51 \mu \mathrm{m}$ and $0.21 \mu \mathrm{m}$, respectively.

\subsection{Preparation of sintered compacts}

The starting materials were mixed with ethanol in ball mill using a plastic pot and iron balls covered with plastic. The mixing ratio of the zirconia powder was constant at $10 \mathrm{vol} \%$, that of the coarse alumina powder was changed at intervals of $10 \mathrm{vol} \%$ from 0 to $90 \mathrm{vol} \%$, and the rest of the mixtures was the fine alumina powder. The powder mixtures containing no zirconia were also prepared similarly. Besides, magnesium nitrate of which was equivalent to the content $0.1 \mathrm{wt} \% \mathrm{MgO}$ was added to all mixtures. After mixing, the powder mixtures were dried, calcined and passed through 100 mesh sieve. The prepared powder mixtures were compacted by isostatic press at $98 \mathrm{MPa}$ and then fired at $1400-1600^{\circ} \mathrm{C}$ for 2 $h$. In this report, the mixing ratio of the starting materials is shown by volume percent of the coarse alumina powder, $V_{\mathrm{c}}$. The specimens containing 10 vol\% zirconia and those containing no zirconia are denoted by $\mathrm{ZA}$ and $\mathrm{AL}$, respectively.

\subsection{Measurement and observation}

Green density was determined from its weight and volume. Sintered density was measured by the Archimedes' method. Relative density of ZA compacts was calculated using the theoretical density $\left(d_{\mathrm{th}}\right)$ determined by the following equation.

$$
d_{\mathrm{th}}=0.9 d_{\mathrm{Al}_{2} \mathrm{O}_{3}}+0.1 d_{\mathrm{ZrO}_{2}}
$$

The theoretical density of alumina $\left(d_{\mathrm{Al}_{2} \mathrm{O}_{3}}\right)$ was 3.987 $\mathrm{g} / \mathrm{cm}^{3}$, that of zirconia $\left(d_{\mathrm{ZrO}_{2}}\right)$ for the sintered compact was $6.097 \mathrm{~g} / \mathrm{cm}^{3}$ (tetragonal zirconia),5) but when the relative density of $\mathrm{ZA}$ green compacts was calculated, the density of zirconia powder was substituted for the theoretical density of zirconia because crystallinity of zirconia powder is low. The density of zirconia powder was $5.76 \mathrm{~g} / \mathrm{cm}^{3}$, which was measured by the pycnometer method. Open pore size distribution was measured using $\mathrm{Hg}$ porosimeter (Poresizer 9310; Micromeritics Co., USA). Microstructure was observed using scanning electron microscope (SEM; JSM-T20, JEOL). Sintered compacts used for the SEM observation were polished and thermally etched at $100^{\circ} \mathrm{C}$ lower than the firing temperature for $1 \mathrm{~h}$. Alumina grain sizes were measured by the intercept method using the SEM photographs of sintered compacts. The properties of ZA specimens were compared with those of $\mathrm{AL}$ specimens which had the same $V_{\mathrm{c}}$ value.

\section{Results and discussion}

\subsection{Packing of green compacts}

The relative densities and the pore size distributions of $\mathrm{ZA}$ and $\mathrm{AL}$ green compacts are shown in Fig. 1 and Fig. 2, respectively. The relative densities of ZA green compacts were almost the same values as those of $\mathrm{AL}$ green compacts having the same $V_{\mathrm{c}}$ value. However, the pore size distributions of ZA green compacts shifted to smaller size than those of AL green compacts. These shifts of the pore size distributions resulted from the fact that the particle size of the zirconia powder was smaller than that of the fine alumina powder.

\subsection{Densification behavior}

The relative densities of $\mathrm{ZA}$ and $\mathrm{AL}$ compacts fired at 1400,1500 and $1600^{\circ} \mathrm{C}$ for $2 \mathrm{~h}$ are shown in Fig. 3. The relative densities of $\mathrm{ZA}$ compacts were lower than those of $\mathrm{AL}$ compacts at $1400^{\circ} \mathrm{C}$ for $V_{\mathrm{c}}$ $=0-90 \%$ and at $1500^{\circ} \mathrm{C}$ for $V_{\mathrm{c}}=60-90 \%$. However, the relative densities of $Z A$ compacts became almost the same as those of $\mathrm{AL}$ compacts at $1600^{\circ} \mathrm{C}$ for $V_{\mathrm{c}}$ $=60-90 \%$ and higher than those of AL compacts at 1500 and $1600^{\circ} \mathrm{C}$ for $V_{\mathrm{c}}=0-50 \%$.

The relative densities of $\mathrm{ZA}$ and $\mathrm{AL}$ compacts for

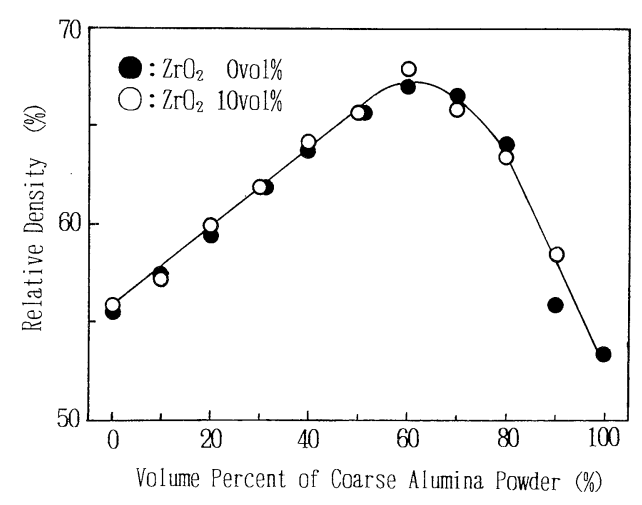

Fig. 1. Relative densities of AL green compacts $(\mathbf{O})$ and $\mathrm{ZA}$ green compacts $(\bigcirc)$ for various $V_{c}$.

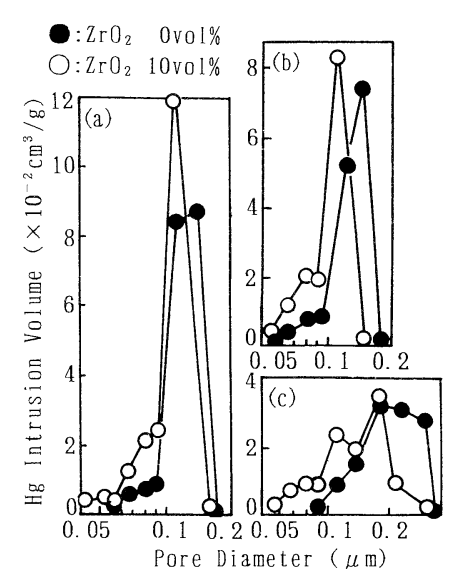

Fig. 2. Pore size distributions of AL green compacts $(-)$ and ZA green compacts $(O)$ for $V_{\mathrm{c}}=0 \%(\mathrm{a}), V_{\mathrm{c}}=30 \%$ (b) and $V_{\mathrm{c}}$ $=70 \%(\mathrm{c})$. 


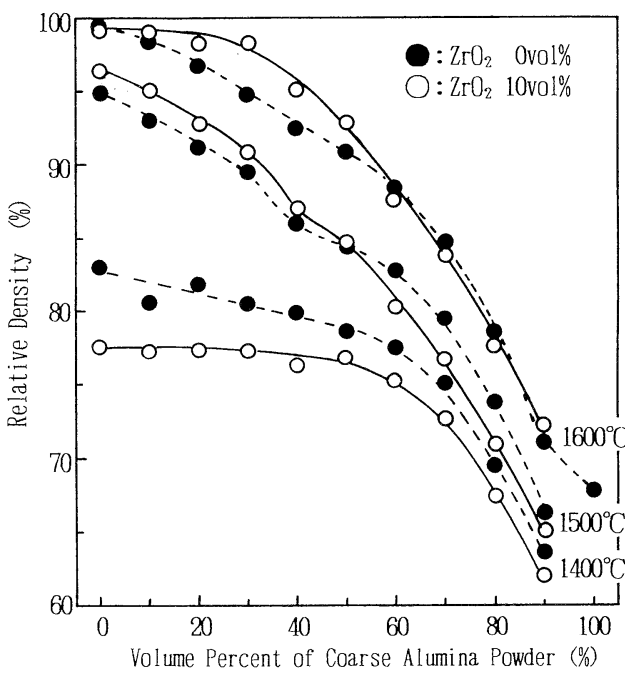

Fig. 3. Relative densities of AL compacts ( ) and ZA compacts (O) for various $V_{\mathrm{c}}$ fired at 1400,1500 and $1600^{\circ} \mathrm{C}$ for $2 \mathrm{~h}$.

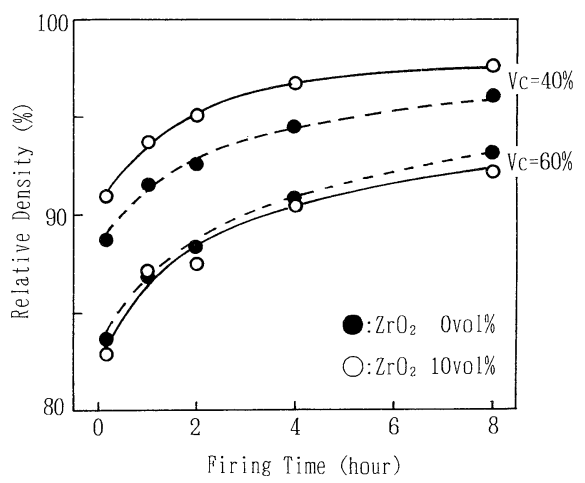

Fig. 4. Relative densities of AL compacts (O) and ZA compacts (O) for $V_{\mathrm{c}}=40 \%$ and $60 \%$ fired at $1600^{\circ} \mathrm{C}$ for $0.1-8 \mathrm{~h}$.

$V_{\mathrm{c}}=40$ and $60 \%$ fired at $1600^{\circ} \mathrm{C}$ for $0.1-8 \mathrm{~h}$ are shown in Fig. 4. For $V_{\mathrm{c}}=40 \%$, the relative densities of ZA compact were $2-3 \%$ higher than those of $\mathrm{AL}$ compact. However, for $V_{\mathrm{c}}=60 \%$, the relative densities of ZA compact become almost the same as those of AL compact but not higher than those of AL compact though the densification proceeded with firing time.

\subsection{Average open pore size}

The average open pore sizes of $\mathrm{ZA}$ and $\mathrm{AL}$ compacts for $V_{\mathrm{c}}=0,30$ and $70 \%$ fired at $1400-1600^{\circ} \mathrm{C}$ for $2 \mathrm{~h}$ are shown in Fig. 5. The average open pore size of AL compact for $V_{\mathrm{c}}=0 \%$ decreased and that for $V_{\mathrm{c}}=30$ and $70 \%$ increased with an increase in firing temperature. These changes were the same tendency as the results in the previous study. ${ }^{3}$ ) On the other hand, the average open pore sizes of ZA compacts for $V_{\mathrm{c}}=0,30$ and $70 \%$ became larger than those of $\mathrm{AL}$ compacts at $1400^{\circ} \mathrm{C}$ though those of $\mathrm{ZA}$ green compacts were smaller than those of AL green compacts. With an increase in firing temperature, the average open pore size of ZA compacts for $V_{\mathrm{c}}=0$

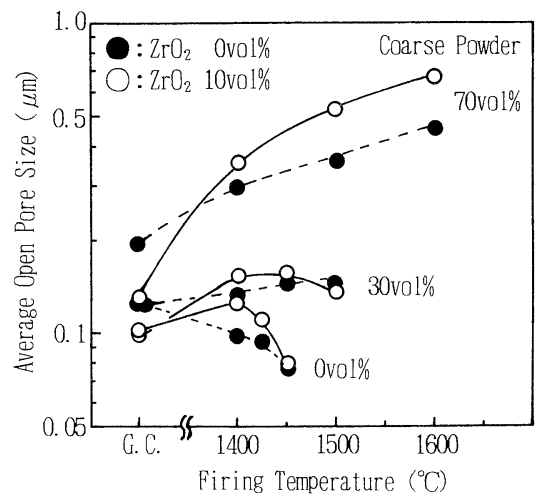

Fig. 5. Plots of average open pore size of $\mathrm{AL}$ compacts $(\mathbf{O})$ and $Z$ A compacts $(O)$ for $V_{\mathrm{c}}=0 \%, V_{\mathrm{c}}=30 \%$ and $V_{\mathrm{c}}=70 \%$ versus firing temperature.

and $30 \%$ decreased, but that for $V_{\mathrm{c}}=70 \%$ increased furthermore.

\subsection{Sintering behavior}

Packing structure of powder mixtures depends on the mixing ratio of the fine and the coarse powders. ${ }^{9}$ ) We classified the packing structures into three groups in the previous study ${ }^{3)}$ and they are as follows. (a); $V_{\mathrm{c}}=0-40 \%$, for which the coarse particles disperse in the matrix of the fine particles. (b); $V_{\mathrm{c}}$ $=70-100 \%$, for which the fine particles fill the voids of skeletal structure formed by the coarse particles. And $(\mathrm{c}) ; V_{\mathrm{c}}=50-60 \%$, for which packing structures of types (a) and (b) co-exist. The packing structure models for types (a) and (b) are schematically shown in Fig. 6.

The influence of zirconia addition on the sintering at high temperature was different between the compacts for $V_{\mathrm{c}}=0-50 \%$ and those for $V_{\mathrm{c}}=60-90 \%$ as shown in Fig. 3. That is, zirconia promoted the densification of the compacts when the packing structure of type (a) was dominant in the green compacts, whereas zirconia did not promote the densification of the compacts when the packing structure of type (b) was dominant in the green compacts.

3.4.1 Sintering behavior for $V_{c}=0-50 \%$

Zirconia particles retard the sintering among alumina particles $\left.{ }^{4)}, 5\right)$ and the pore size becomes larger
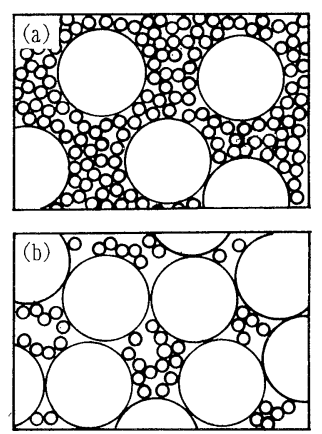

Fig. 6. Schematic packing structures of the bimodal size distributed powder mixtures; Packing structures for $V_{\mathrm{c}}=0-40 \%$ (a) and for $V_{\mathrm{c}}=70-90 \%(\mathrm{~b})$. 
when non-uniform sintering occurs. ${ }^{10)}$ The relative densities of ZA compacts fired at $1400^{\circ} \mathrm{C}$ were lower than those of $\mathrm{AL}$ compacts (Fig. 3) and the pore sizes of ZA compacts fired at $1400^{\circ} \mathrm{C}$ become larger than those of ZA green compacts (Fig. 5). These facts indicate that the sintering among alumina particles in ZA compacts at $1400^{\circ} \mathrm{C}$ is retarded by zirconia particles and such retardation causes non-uniform sintering around zirconia particles.

The previous studies ${ }^{1), 3}$ indicated the sintering behavior of bimodal alumina powder mixtures at high firing temperature as follows; The shrinkage rate between the coarse particles is slow, whereas the densification among the fine particles proceeds furthermore. As the results, large pores form around coarse particles and the densification of the compacts depends on the shrinkage between coarse particles. Next, SEM photographs of ZA and AL compacts for $V_{\mathrm{c}}=30 \%$ fired at 1500 and $1600^{\circ} \mathrm{C}$ for $2 \mathrm{~h}$ are shown in Fig. 7. In AL compact, large pores formed around the coarse alumina particles at $1500^{\circ} \mathrm{C}$ and a remarkable grain growth occurred at $1600^{\circ} \mathrm{C}$. These facts were similar to those in the previous studies. ${ }^{1)-3)}$ On the other hand, in ZA compact, the densification around the coarse alumina particles proceeded more than that in $\mathrm{AL}$ compact at $1500^{\circ} \mathrm{C}$. Such microstructure of ZA compact was considered to be developed by following way. The densification among the fine alumina particles was retarded by zirconia particles at low firing temperature, so that the contacts between the fine and the coarse alumina particles maintained up to higher firing temperature. Consequently, the densification between the fine and the coarse alumina particles, that is, around the coarse alumina particles proceeded more than that in AL compact at $1500^{\circ} \mathrm{C}$. Also, it was observed in ZA compact fired at $1600^{\circ} \mathrm{C}$ that the alumina grains were smaller than those in $\mathrm{AL}$ compact and zirconia particles located
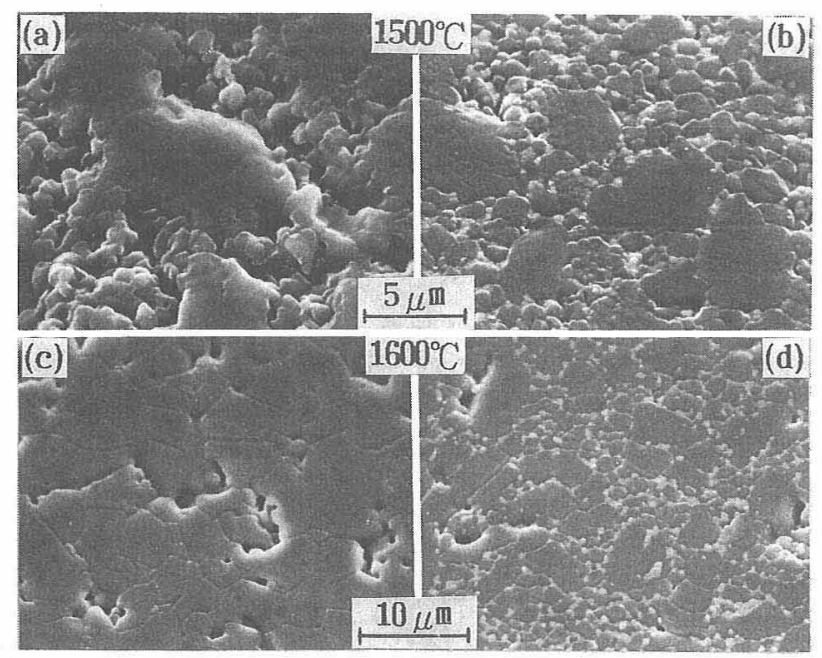

Fig. 7. SEM photographs of AL compact and ZA compact for $V_{c}$ $=30 \% ; \mathrm{AL}$ compact sintered at $1500^{\circ} \mathrm{C}$ (a), ZA compact sintered at $1500^{\circ} \mathrm{C}(\mathrm{b}), \mathrm{AL}$ compact sintered at $1600^{\circ} \mathrm{C}$ (c) and $\mathrm{ZA} \mathrm{com-}$ pact sintered at $1600^{\circ} \mathrm{C}(\mathrm{d})$. and grew between alumina grains. This microstructure indicates that zirconia hindered the grain growth of alumina so that the densification among alumina particles in ZA compact proceeded more than that in AL compact. And it is obvious that zirconia particles migrated with grain boundary and located at three- or four-grain junctions during the slow grain growth of alumina in the same way reported by Lange and Hirlinger. ${ }^{6)}$ When some zirconia particles migrated to the region, for example around the coarse alumina particles, where the large pores formed in case of AL compact, large pores were probably difficult to form in ZA compact. Above discussion could explain the results that ZA compacts had higher relative density than $\mathrm{AL}$ compacts at 1500 and $1600^{\circ} \mathrm{C}$ and the average open pore size of $\mathrm{ZA}$ compact decreased at high temperature as shown in Fig. 3 and Fig. 5.

For $V_{\mathrm{c}}=0 \%$, the above explanation is not applicable because there are no coarse alumina particles. SEM photographs of ZA and AL compacts for $V_{\mathrm{c}}$ $=0 \%$ fired at 1450 and $1500^{\circ} \mathrm{C}$ for $2 \mathrm{~h}$ are shown in Fig. 8. In AL compact, the densification occurred mainly within the intra-agglomerate particles at $1450^{\circ} \mathrm{C}$ and many pores of about $1 \mu \mathrm{m}$ in size remained at $1500^{\circ} \mathrm{C}$. On the other hand, in $\mathrm{ZA}$ compact, the densification proceeded more uniformly than that in $\mathrm{AL}$ compact at $1450^{\circ} \mathrm{C}$ and large pores almost never form appreciably at $1500^{\circ} \mathrm{C}$. These microstructures of ZA compact indicate that the densification within the intra-agglomerate particles was retarded by zirconia particles so that the densification not only within the intra-agglomerate particles but also between the agglomerate particles proceeded at higher firing temperature. Such densification process explained the results that ZA compact for $V_{\mathrm{c}}$ $=0 \%$ had higher relative density than $\mathrm{AL}$ compact at 1500 and $1600^{\circ} \mathrm{C}$ as shown in Fig. 3.
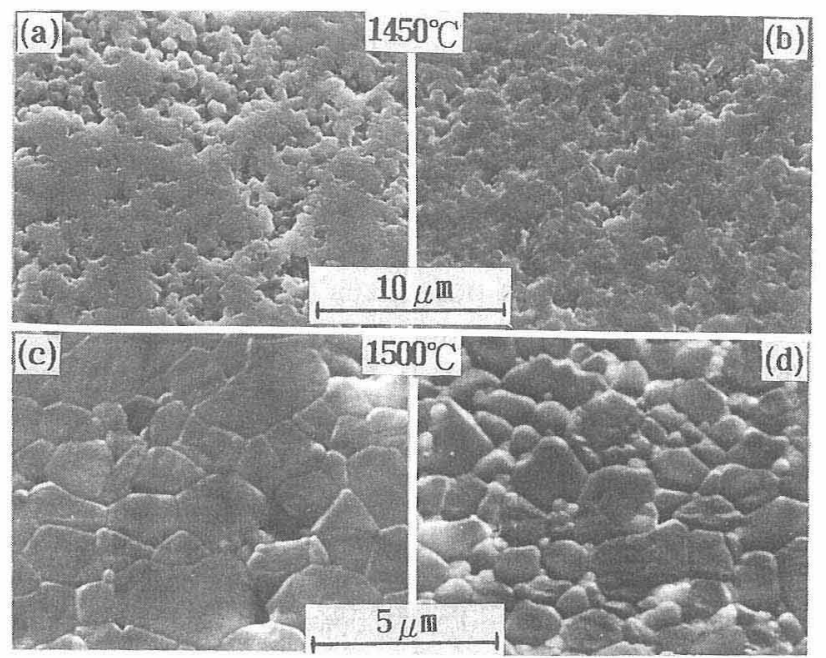

Fig. 8. SEM photographs of AL compact and ZA compact for $V_{c}$ $=0 \% ; \mathrm{AL}$ compact sintered at $1450^{\circ} \mathrm{C}(\mathrm{a}), \mathrm{ZA}$ compact sintered at $1450^{\circ} \mathrm{C}(\mathrm{b}), \mathrm{AL}$ compact sintered at $1500^{\circ} \mathrm{C}$ (c) and $\mathrm{ZA} \mathrm{com-}$ pact sintered at $1450^{\circ} \mathrm{C}(\mathrm{d})$. 


\subsubsection{Sintering behavior for $V_{\mathrm{c}}=60-90 \%$}

If the powder mixtures for $V_{\mathrm{c}}=70-90 \%$ formed the ideal Furnas packing structure, ${ }^{11)}$ coarse particles form a skeletal structure and fine particles fill the spaces of the skeletal structure. In such a packing structure, the densification of the compacts depends on only the densification among coarse particles. ${ }^{12)}$ However, in fact, the relative densities of ZA compacts fired at $1400^{\circ} \mathrm{C}$ was lower than those of AL compacts as shown in Fig. 3, that is, zirconia particles retarded the densification among the coarse alumina particles. This fact indicates that the fine alumina and zirconia particles probably influenced the densification of the compacts because actually the fine alumina and zirconia particles partially surrounded the coarse alumina particles as shown in the previous studies. ${ }^{1-3)}$

SEM photographs of ZA and AL compacts for $V_{c}$ $=70 \%$ fired at 1500 and $1600^{\circ} \mathrm{C}$ for $2 \mathrm{~h}$ are shown in Fig. 9. In $\mathrm{AL}$ compact fired at $1500^{\circ} \mathrm{C}$, agglomerates of sintered fine alumina particles formed in the spaces of the skeletal structure of the coarse alumina particles. However, such agglomerates in ZA compact were smaller than those in AL compact. Also, zirconia particles dispersed on the coarse alumina particles. The formation of such different agglomerates in size was the cause for the fact that the pore size of ZA compact became larger than that of $\mathrm{AL}$ compact at $1400^{\circ} \mathrm{C}$ as shown in Fig. 5 .

Figure 3 shows that the densification among alumina particles in ZA compacts, which was retarded by zirconia particles at 1400 and $1500^{\circ} \mathrm{C}$, proceeded more rapidly between 1500 and $1600^{\circ} \mathrm{C}$. Also, Fig. 9 shows that the grain growth of alumina proceeded in both ZA and AL compacts and zirconia particles located at three- or four-point junctions of alumina grains at $1600^{\circ} \mathrm{C}$. These facts indicate that the densification of both ZA and AL compacts depended on

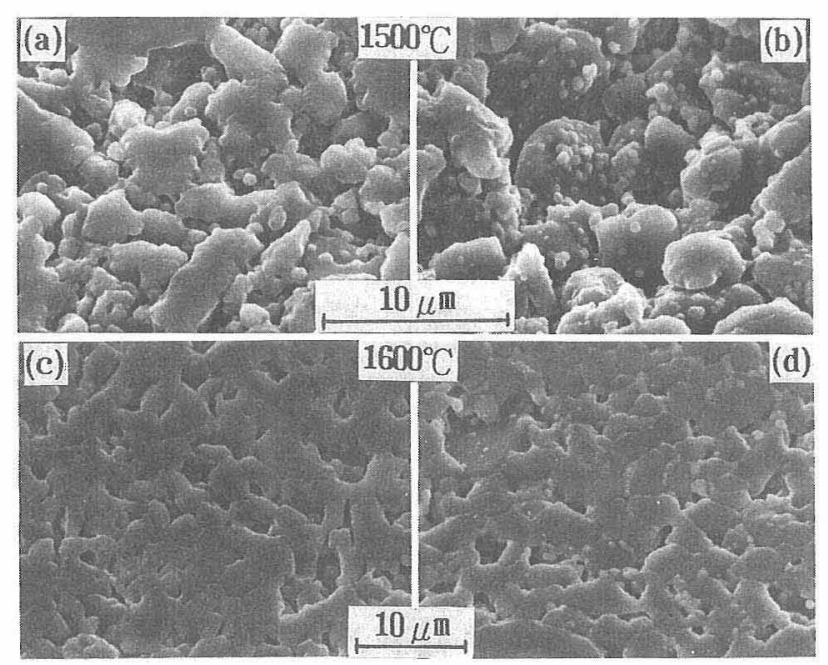

Fig. 9. SEM photographs of AL compact and ZA compact for $V_{\mathrm{c}}$ $=70 \%$; AL compact sintered at $1500^{\circ} \mathrm{C}$ (a), ZA compact sintered at $1500^{\circ} \mathrm{C}$ (b), AL compact sintered at $1600^{\circ} \mathrm{C}$ (c) and ZA compact sintered at $1600^{\circ} \mathrm{C}$ (d). only the densification among the large alumina particles at $1600^{\circ} \mathrm{C}$. Such densification process was the cause for the fact that the relative densities of $\mathrm{ZA}$ and $\mathrm{AL}$ compacts were almost the same at $1600^{\circ} \mathrm{C}$ though the densification proceeded with firing time as shown in Fig. 4.

\subsubsection{Alumina grain size}

The plots of the average grain size of alumina in $\mathrm{ZA}$ and $\mathrm{AL}$ compacts for $V_{\mathrm{c}}=40$ and $60 \%$ fired at $1600^{\circ} \mathrm{C}$ for $2-8 \mathrm{~h}$ versus the relative density are shown in Fig. 10. The difference between the average grain sizes of alumina in $\mathrm{ZA}$ and $\mathrm{AL}$ compacts for $V_{\mathrm{c}}=40 \%$ was not large at the relative density of around $90 \%$. That is, the hindrance effect of zirconia on the grain growth of alumina was a little in the intermediate stage of sintering. However, at the relative density of larger than $90 \%$, the average grain size in AL compact enlarged remarkably, which resulted in the large difference between the average grain sizes in ZA and AL compacts. That is, zirconia particles hindered the grain growth of alumina in the final stage of sintering. The SEM photographs used for grain size measurement, which are not presented in this paper, showed that the grain growth of alumina proceeded as follows; Initially, the grain growth between the fine alumina particles and between the fine and the coarse alumina particles occurred. Subsequently, the grain growth between relatively small grains to which the fine alumina particles grew and between such the small grain and growing coarse alumina particle proceeded. Zirconia particles hindered such grain growth. However, the grain growth between the coarse alumina particles and between large grains to which the fine or the coarse alumina particles grew was difficult to occur in even AL compact under this experimental condition.

The average grain size of alumina in ZA compact for $V_{\mathrm{c}}=60 \%$ was almost the same as that in AL compact even at the relative density of larger than $90 \%$. The grain growth of alumina in the compact for $V_{\mathrm{c}}$ $=60 \%$ proceeded as well as that for $V_{c}=40 \%$.

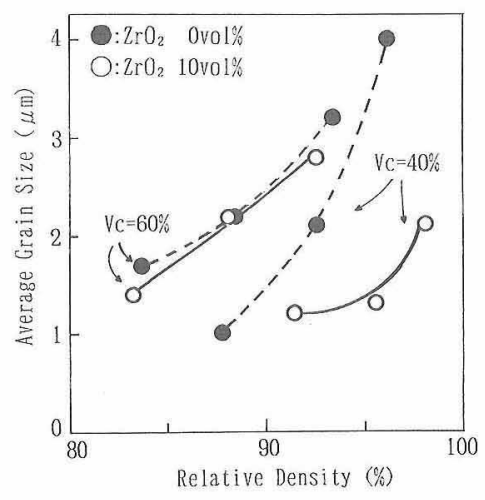

Fig. 10. Plots of average grain size of alumina in AL compacts (O) and ZA compacts $(O)$ for $V_{\mathrm{c}}=40 \%$ and $60 \%$ versus relative density. 
However, the grain growth rate of alumina in $\mathrm{AL}$ compact for $V_{\mathrm{c}}=60 \%$ was slower than that for $V_{\mathrm{c}}$ $=40 \%$ because the grain growth between the coarse alumina particles and between large grains to which the fine or the coarse alumina particles grew was difficult to occur. On the other hand, zirconia particles in ZA compact for $V_{\mathrm{c}}=60 \%$ migrated with grain boundary more easily than those for $V_{c}=40 \%$ because both of pore size and pore volume in $\mathrm{ZA} \mathrm{com-}$ pact for $V_{\mathrm{c}}=60 \%$ were larger than those for $V_{\mathrm{c}}$ $=40 \%$. As the results of these facts, zirconia particles did not contribute to the hindrance for the grain growth of alumina under this experimental condition.

\section{Conclusion}

In this study, we have discussed the influence of zirconia addition on the sintering behavior of the bimodal size distributed alumina powder mixtures. As the results, following conclusions were obtained.

(1) Zirconia particles do not influence the relative density of the green compacts, but make the pore size of green compacts small because zirconia particles have smaller size than fine alumina particles.

(2) Zirconia particles retard the densification of the compacts and enlarge the pore size at low firing temperature, that is, in the initial stage of sintering.

(3) Influence of zirconia addition on the sintering behavior at high firing temperatures is different, depending on the packing structure of the green compacts.

(4) When most of the coarse particles disperse in the matrix of the fine particles, that is, the volume percent of the coarse alumina powder is $0-50 \%$, zirconia promotes the densification of the compacts and makes the pore size smaller. This result is explained by the promotion of sintering between the fine and the coarse alumina particles and/or between ag- glomerate particles in the intermediate stage of sintering and by the migration of zirconia and the hindrance effect of zirconia on the grain growth of alumina in the final stage of sintering.

(5) When the coarse particles form the skeletal structure, that is, the volume percent of the coarse alumina powder is $60-90 \%$, the relative densities of the compacts containing zirconia become almost the same as those containing no zirconia. However, even if the densification proceeds furthermore, the relative densities of the compacts containing zirconia do not become higher than those containing no zirconia. This result is explained by the dependence of the densification of the compacts only on the densification among large alumina particles.

\section{References}

1) S. Taruta, K. Kitajima, N. Takusagawa, K. Okada and N. Ōtsuka, J. Ceram. Soc. Japan, 101, 583-88 (1993).

2) S. Taruta, K. Kitajima, N. Takusagawa, K. Okada and N. Ōtsuka, Seramikkusu Ronbunshi, 99, 1189-94 (1991).

3) S. Taruta, K. Okada and N. Ōtsuka, Seramikkusu Ronbunshi, 98, 29-35 (1990).

4) F. F. Lange, T. Yamaguchi, B. I. Davis and P. E. D. Morgan, J. Am. Ceram. Soc., 71, 446-48 (1988).

5) S. Hori, "Two-Component Oxide Ceramics from CVD Powders", Ed. by S. Sōmiya, Uchida Rokakuho (1988) pp. 97116.

6) F. F. Lange and M. M. Hirlinger, J. Am. Ceram. Soc., 67, 164-68 (1984).

7) J. Wang and R. Raj, J. Am. Ceram. Soc., 74, 1959-63 (1991).

8) B. Kibbel and A. H. Heuer, J. Am. Ceram. Soc., 69, 231-36 (1986).

9) D. J. Cumberland and R. J. Crawford, "Handbook of Powder Technology", Vol. 6; "The Packing of Particles", Elsevier, Amsterdam (1987) pp. 41-61.

10) M. W. Weiser and L. C. De Jonghe, J. Am. Ceram. Soc., 69, 822-26 (1986).

11) C. C. Furnas, U. S. Bur. Mines. Rep. Invest., No. 2894 (1928).

12) G. L. Messing and G. Y. Onoda, Jr., J. Am. Ceram. Soc., 64, 468-72 (1981). 